\title{
New endemic West Nile virus lineage la in northern Italy, July 2012
}

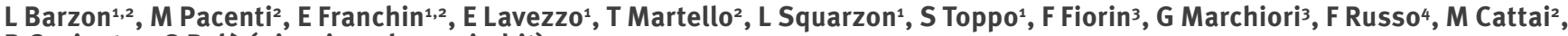
R Cusinato ${ }^{2}$, G Palù (giorgio.palu@unipd.it) ${ }^{1,2}$

1. Department of Molecular Medicine, University of Padova, Padova, Italy

2. Regional Reference Laboratory for Infectious Diseases, Microbiology and Virology Unit, Padova University Hospital, Padova, Italy

3. Department of Transfusion Medicine, Venetian Area, Venice, Italy

4. Department of Public Health and Screening, Veneto Region, Venice, Italy

Citation style for this article:

Barzon L, Pacenti M, Franchin E, Lavezzo E, Martello T, Squarzon L, Toppo S, Fiorin F, Marchiori G, Russo F, Cattai M, Cusinato R, Palù G. New endemic West Nile virus lineage $1 \mathrm{a}$ in northern Italy, July 2012. Euro Surveill. 2012;17(31):pii=20231. Available online: http://www.eurosurveillance.org/ViewArticle.

aspx?Articleld $=20231$

Article submitted on 26 July 2012 / published on 2 August 2012

We report here the first blood donation positive for West Nile virus (WNV) by nucleic acid amplification testing collected in north-eastern Italy in July 2012. Partial sequencing of the WNV RNA demonstrated identity with a WNV lineage 1 a genome identified in the same area in 2011 and divergence from the strain responsible for the outbreak in northern Italy in 200809. These data indicate that WNV activity in northern Italy is occurring earlier than expected and that different WNV strains are circulating.

As part of the screening of blood, tissue, and organ donations, performed in Italy according to the national plan in the period between 15 July and 30 November, West Nile virus (WNV) was detected by nucleic acid amplification test (NAAT) in a blood donation on 15 July 2012. NAAT was performed at the Department of Transfusion Medicine in Venice Province using the automated Procleix TIGRIS System (Novartis Vaccines and Diagnostics, Inc., Emeryville, CA, USA). At the time of the donation the WNV-positive donor was asymptomatic and remained asymptomatic during follow-up. The Regional Reference Laboratory demonstrated low viral load in plasma by real-time quantitative RT-PCR (approximately 1,000 genome equivalents $/ \mathrm{mL}$ ) and the absence of WNV IgM and IgG at the time of donation (tested by WNV IgM Capture DxSelect and WNV IgG DxSelect; Focus Diagnostics Inc., Cypress, CA, USA).

Two days after the donation, fresh blood and urine samples were taken from the donor and tested by the Regional Reference Laboratory using the Cobas TaqScreen West Nile Virus Test (Roche, Basel, Switzerland) and two different real-time RT-PCR methods, as reported [1]. In these specimens, WNV RNA was demonstrated in serum and plasma but not in urine, and the presence of WNV IgM in serum. Follow-up testing nine days after the donation demonstrated that plasma, leukocytes, and urine specimens were WNV RNA-negative. Unfortunately, virus isolation in cell culture was not successful.

\section{Epidemiology of West Nile virus in Italy} WNV has emerged in recent years in central European, eastern European and Mediterranean countries, and epidemics in these areas have become increasingly frequent [2]. In Italy, the virus was first identified in horses in 1998 in Tuscany, but no human cases were identified at the time [3]. The first human cases of WNV disease were identified in 2008, in north-eastern Italian regions surrounding the delta of the river Po $[4,5]$. In these areas, in 2008 and 2009, several human cases of WNV disease were identified, large outbreaks occurred among horses, and widespread WNV circulation was demonstrated by screening of birds and mosquitoes $[6,7]$. Genome sequence analysis of WNV strains isolated in Italy in 2008 and 2009 showed they were closely related $[6,8,9]$, suggesting the virus had overwintered and established an endemic cycle in Italy. Provinces affected by WNV circulation are indicated in Figure 1. In 2010, human cases of WNV disease were reported only in the region Veneto (Figure 1), where special surveillance programmes for West Nile fever had been activated $[1,10]$, and virus circulation was recorded in more northern areas than those affected in previous years [1]. In two blood donations from Veneto in 2010, typing was possible and WNV lineage 1 was identified by specific real-time RT-PCR, but due to the low viral load, viral genome sequencing was unsuccessful [1]. In 2011, increased WNV activity was observed in Italy, involving a larger geographic territory in north-eastern regions (Figure 1) as well as the regions Sardinia and Marche, where WNV circulation had not been reported before [11].

\section{Phylogenetic analysis}

WNV RNA was amplified and sequenced from the plasma of the positive donor identified in July 2012. Fragments of the WNV E (278 nt), NS2B-NS3 (721 nt), and $\mathrm{NS}_{5}$ genes (182 nt) (GenBank accession number JX417422) demonstrated $100 \%$ sequence identity with the WNV Livenza genome (GenBank accession no. JQ928174) that was detected in September 2011 


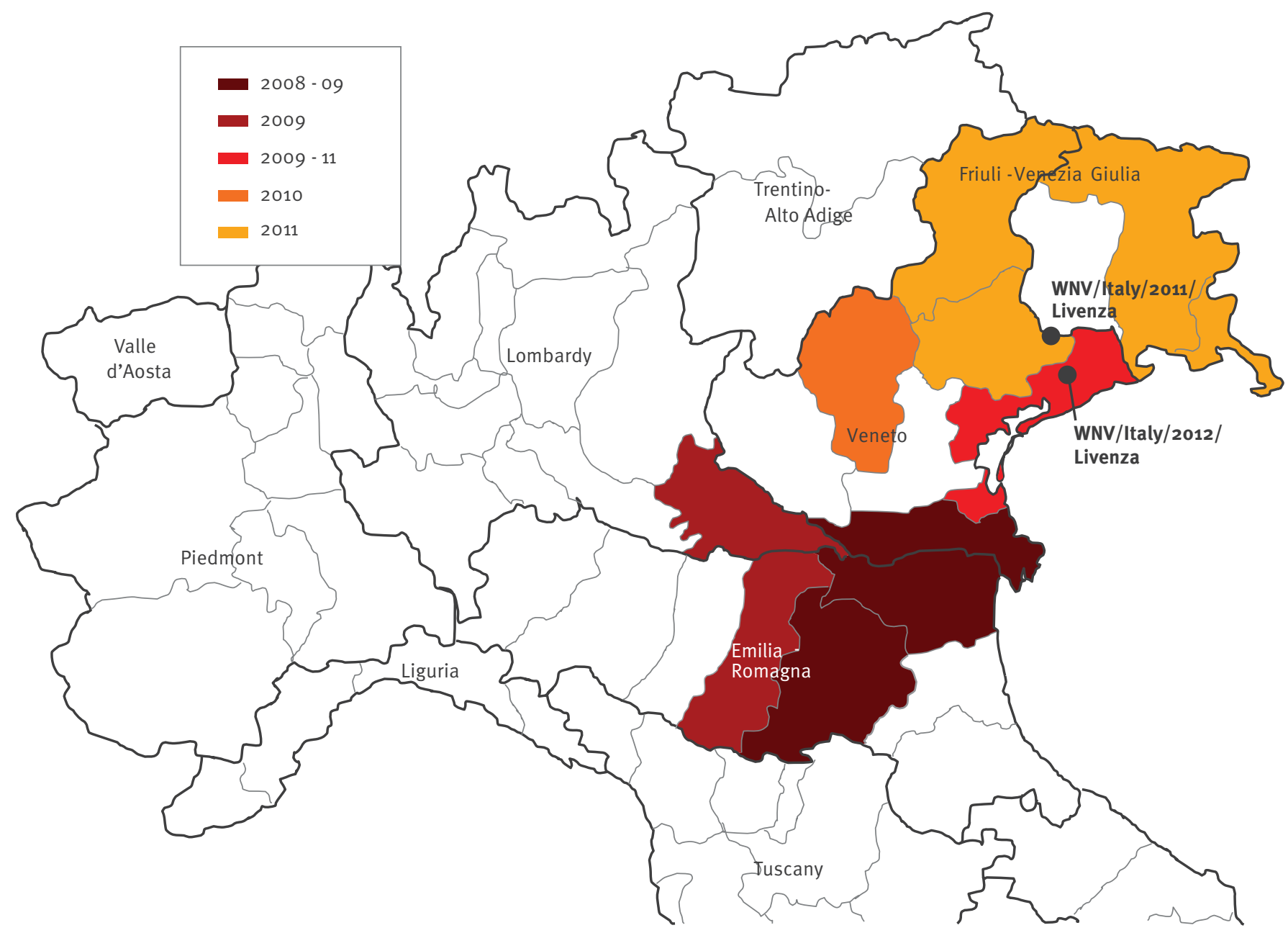

The area where the 2012 case of WNV infection was detected is indicated by a black dot. The WNV/Italy/2012/Livenza RNA sequence obtained from this case was deposited in GenBank (accession number JX417422). The site where WNV/Italy/2011/Livenza (GenBank accession number JQ928174) was identified is also indicated.

in a blood donor resident in a nearby village, and fully sequenced (Figure 2). Both genome sequences belonged to lineage 1a and were related to WNV strains of the western Mediterranean subtype.

A further lineage 1a WNV genome sequence, WNV Piave (GenBank accession numbers JQ928175), had been obtained in 2011 from biological samples collected from a transplant recipient. However, the two WNV genomes from 2011 had a high nucleotide and amino acid sequence divergence from each other and from the WNV strain circulating in Italy in 2008-09 (Figure 2).

\section{Discussion}

The WNV-positive donor identified in July 2012 was resident in a village in Venice Province, located near the Livenza River (Figure 1). Sequence analysis of viral RNA from the donor demonstrated $100 \%$ sequence identity with a WNV genome that was fully sequenced the year before from a blood donor resident in a nearby village (Figure 2). This finding strongly suggests overwintering of the so-called WNV Livenza strain in the wetland area surrounding the Livenza River in north-eastern Italy, where it has probably established an endemic cycle.

In 2012 , as in previous years [1,11], the surveillance period for human cases of WNV disease in affected areas in Italy lasts from 15 June to 30 November, while the period for WNV nucleic acid amplification test (NAAT) screening of blood, tissue, and organ donations lasts from 15 July to 30 November. Since most human cases of WNV infection detected in Italy so far have been identified during September, when mosquito activity is highest, and fewer cases in August and October, it was unexpected to find a WNV NAAT-positive blood 


\section{FIGURE 2}

Molecular phylogenetic comparison of the West Nile virus strain isolated in Italy in 2012 with older strains

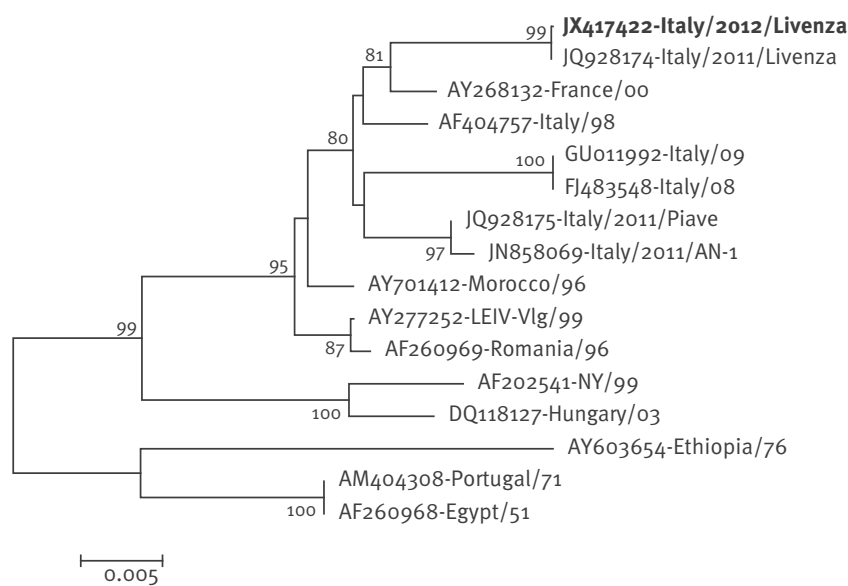

The phylogenetic tree was inferred using the maximum likelihood method based on the Jukes-Cantor model [12] on a fragment of 721 nt covering a genomic region across the NS2B and NS3 genes. The percentage of successful bootstrap replicates $(n=1,000)$ is shown on the nodes (only values $\geq 80$ are shown). Evolutionary analyses were conducted in MEGA 5 [13]. The bootstrap value of 99 (instead of 100) is due to an approximation made by the phylogenetic software when performing bootstrapping. The phylogenetic trees constructed with a fragment of $278 \mathrm{nt}$ of the E gene and a fragment of $182 \mathrm{nt}$ of the NS5 gene gave similar results.

donation as early as on the first day of blood screening on 15 July 2012.

Such an early detection of a human case of infection during the 2012 season might predict increased WNV activity, requiring strengthened surveillance. It is conceivable that the warm spring and very hot summer in north-eastern Italy may have favoured WNV spread due to increased mosquito density. This year, early detection of human cases of WNV disease has been reported also in Sardinia, in Greece, Israel, and the occupied Palestinian territory [14], and this trend might predict increased viral activity in the Mediterranean area.

In conclusion, this study reports a new endemic WNV strain detected in north-eastern Italy responsible for a human case of infection early in the summer 2012. This study also indicates the importance of WNV NAAT screening for the safety of blood, tissue, and organ donations.
References

1. Barzon L, Pacenti M, Cusinato R, Cattai M, Franchin E, Pagni S, et al. Human cases of West Nile Virus infection in north-eastern Italy, 15 June to 15 November 2010. Euro Surveill. 2011;16(33): pii=19949. Available from: http://www. eurosurveillance.org/ViewArticle.aspx?Articleld=19949

2. Reiter P. West Nile virus in Europe: understanding the present to gauge the future. Euro Surveill. 2010;15(10):pii=19508. Available from: http://www.eurosurveillance.org/ViewArticle. aspx?Articleld $=19508$

3. Autorino GL, Battisti A, Deubel V, Ferrari G, Forletta R, Giovannini A, et al. West Nile virus epidemic in horses, Tuscany region, Italy. Emerg Infect Dis. 2002;8(12):1372-8.

4. Rossini G, Cavrini F, Pierro A, Macini P, Finarelli A, Po C, et al. First human case of West Nile virus neuroinvasive infection in Italy, September 2008 - case report. Euro Surveill. 2008;13(41):pii=19002. Available from: http://www. eurosurveillance.org/ViewArticle.aspx?Articleld=19002

5. Barzon L, Squarzon L, Cattai M, Franchin E, Pagni S, Cusinato $\mathrm{R}$, et al. West Nile virus infection in Veneto region, Italy, 2008-2009. Euro Surveill. 2009;14(31):pii=19289. Available from: http://www.eurosurveillance.org/ViewArticle. aspx?Articleld=19289

6. Barzon L, Franchin E, Squarzon L, Lavezzo E, Toppo S, Martello T, et al. Genome sequence analysis of the first human West Nile virus isolated in Italy in 2009. Euro Surveill. 2009;14(44):pii=19384. Available from: http://www. eurosurveillance.org/ViewArticle.aspx?Articleld=19384

7. Rizzo C, Vescio F, Declich S, Finarelli AC, Macini P, Mattivi A, et al. West Nile virus transmission with human cases in Italy, August-September, 2009. Euro Surveill. 2009;14(40): pii=19353. Available from: http://www. eurosurveillance.org/ViewArticle.aspx?Articleld=19353

8. Rossini G, Carletti F, Bordi L, Cavrini F, Gaibani P, Landini MP, et al. Phylogenetic analysis of West Nile virus isolates, Italy, 2008-2009. Emerg Infect Dis. 2011;17(5):903-6.

9. Sotelo E, Fernández-Pinero J, Llorente F, Vázquez A, Moreno $A$, Agüero $M$, et al. Phylogenetic relationships of Western Mediterranean West Nile virus strains (1996-2010) using fulllength genome sequences: single or multiple introductions? J Gen Virol. 2011;92(Pt11):2512-22.

10. Gobbi F, Barzon L, Capelli G, Angheben A, Pacenti M, Napoletano G, et al. Surveillance for West Nile, dengue, and chikungunya virus infections, Veneto Region, Italy, 2010. Emerg Infect Dis. 2012;18(4):671-3.

11. Rizzo C, Salcuni P, Nicoletti L, Ciufolini MG, Russo F, Masala R, et al. Epidemiological surveillance of West Nile neuroinvasive diseases in Italy, 2008 to 2011. Euro Surveill. 2012;17(20): pii=20172. Available from: http://www. eurosurveillance.org/ViewArticle.aspx?Articleld =20172

12. Jukes TH, Cantor CR. Evolution of protein molecules. In: Munro HN, editor. Mammalian Protein Metabolism. New York: Academic Press;1969. pp. 21-132.

13. Tamura K, Peterson D, Peterson N, Stecher G, Nei M, Kumar S. MEGA5: molecular evolutionary genetics analysis using maximum likelihood, evolutionary distance, and maximum parsimony methods. Mol Biol Evol. 2011;28(10):2731-9.

14. European Centre for Disease Prevention and Control (ECDC). West Nile fever maps. Situation update 26 July 2012. Stockholm: ECDC. [Accessed on 1 August 2012]. Available from: http://ecdc.europa.eu/en/healthtopics/west_nile_fever/ West-Nile-fever-maps/
Funding

This research was funded by Veneto Region, by the EU (FP7 project WINGS, grant no. 261426), and by the University of Padova (grant no. CPDA108383/10) to Giorgio Palù. 